\title{
Evaluation of Barley (Hordeum vulgare, L.) Productivity under Rainfed Conditions in Wadi Hashem (East Matrouh)
}

\author{
Gomaa, M.A. ${ }^{1}$, I.F. Rehab ${ }^{1}$, M.S. Barsoum ${ }^{2}$ and M.K. Kenawy ${ }^{2}$ \\ 1. Plant Production Dep., Faculty of Agriculture (Saba basha) Univ. Alexandria \\ 2. Plant Production Dep., Ecology and Dry Agriculture Division. Desert Research \\ Center, Egypt
}

\begin{abstract}
The main purpose of this investigation was to evaluate the yield, yield attributes and water use efficiency of Giza 126 barley cultivar under rainfed conditions. Two field experiments were carried out in flood plain of Wadi Hashim, Raas El-Hekma Region, East Mersa Matrouh, Matrouh Governorate, North Western Coast of Egypt, during tow winter growing successive seasons (2011/2012 and 2012/2013) to study the effect of size strip of water harvesting (catchment): cultivated area and (mineral nitrogen and biofertilization) on yield, yield components and water use efficiency (WUE) of barley. Results indicated that, yield and yield attributes of barley i.e. number of spike $/ \mathrm{m}^{2}, 1000$ grain weight $(\mathrm{g})$, biological yield $(\mathrm{kg} / \mathrm{fed}$.), grain yield ( $\mathrm{kg} / \mathrm{fed}$.) straw yield ( $\mathrm{kg} / \mathrm{fed}$.) and harvest index were significantly increased with increasing the ratio of catchment area to cultivated area as compared with control (without leaving catchment area) and by increasing mineral nitrogen fertilizer up to $20 \mathrm{~kg} \mathrm{~N} / \mathrm{fed}$. with biofertilization inoculation, but number of tillires $/ \mathrm{m}^{2}$ significantly increased with increasing the ratio of catchment area to cultivated area only in the second season and by increasing mineral nitrogen fertilizer up to $20 \mathrm{~kg} \mathrm{~N} / \mathrm{fed}$. with biofertilization inoculation in the first and second season. Moreover, the water use efficiency $\left(\mathrm{kg} / \mathrm{m}^{3}\right)$ for grain yield was significantly increased in the applied water harvesting and mineral nitrogen fertilizer with biofertilization inoculation treatments as compared with the control. From the economical point of view, the optimum treatment in terms of increasing barley yield potential under rainfall conditions was the ratio of 4:1 (four times of cultivated area) and the high dose of mineral nitrogen with biofertilization inoculation (20 kg N/fed. with microbein) at Wadi Hashim, Raas El-Hekma Region.
\end{abstract}

Keywords: Barley, Water harvesting systems, Mineral nitrogen, Microbein biofertlization

\section{INTRODUCTION}

Rainfed agriculture plays and will continue to play a dominant role in providing food and livelihoods for an increasing world population (Rockstrom et al. 2010). Barley (Hordeum vulgare L.) considered one of the most important cereal crops grown along North Western Coast of Egypt under rainfed conditions. Also, it is grown in the newly reclaimed lands. Barley had been recognized as an adapted crop to adverse conditions and could survive and grow satisfactory under such conditions than several other crops. The major use of barely in North Western Coast of Egypt is for many purposes such as malting, brewing industry, animal feeding and many other uses. However there is recent interest by using the crop in human food (Said, 1998). Rainwater harvesting, based on the collection and storage of rainfall runoff, has been widely used for domestic use and agricultural production in arid and semi arid regions (Jiang et al., 2013). In arid and semi arid regions agriculture development processes where water irrigation is a scarce and costly input for successful crop production, water management studies has become an important aspect. However, water harvesting system is one of the most important asses all over the world. A preliminary survey indicated that a conservation estimate of the area which is currently under runoff irrigation is about 500000 hectares. The problem of water shortage in arid and semi-arid 
regions is one of low rainfall and uneven distribution through out the season, which makes rainfed agriculture a risky enterprise. Therefore new interests came up in recent decades to evaluate traditional water management techniques, most of them being simple, sure to implement and of low capital investment (Prinz and Wolfer, 1999). The classical sources of irrigation water are often at the break of overuse and therefore untapped sources of (irrigation) water have to be sought for increasing agricultural productivity and providing sustained economic base. Water harvesting for dry-land agriculture is a traditional water management technology to ease future water scarcity in many arid and semi-arid regions of world. Water harvesting based on the collecting and concentration of surface runoff for cultivation has been practiced in different parts of the world for thousands years (Reiz et al., 1986). Micro catchments water harvesting $(\mathrm{MCWH})$ which collects runoff from short slops is especially useful in arid and semi arid regions where irrigation water is not available or costly (Boars et al., 1986). Small catchments basins in rainfed valley-bottom filled were allowed. Cost method of generation runoff and increasing grain yields within the cropped areas. The proportions of water catchments area to cropped area (within a given plot) investigated by AZRI had been 1: 1, where half the area was water catchments, half is planted; 2 : 1 , with two thirds water catchments one third planted, and as the controls the traditional practice, in which the entire area planted (Rees et al., 1989) for nomenclature of water harvesting methods. About $70 \%$ of the fresh water consumed world-wide is used for irrigation, while $20 \%$ is used by industry and $10 \%$ for drinking and residential purposes (Brown, 2000). Rainfed areas cover about one million hectares in the North Western Costal of Egypt (with $500 \mathrm{~km}$ long and $20 \mathrm{~km}$ width). The rainfall in the growing season is highly variable and less than barley requirements, consequently water conservation is essential to stabilize the water availability for maximizing crop production and increase yield. Water harvesting systems are mainly practiced in arid and semi-arid areas with annual rainfall ranging from 100-600 $\mathrm{mm}$. In the point of view on Egyptian North Western Coast it can be observed that the term of water harvesting is used to describe the process of collecting and storing water for later beneficial used from an area that has been modified or treated to increase production runoff, the collected water can be used for most purposes of domestic uses and growing of plants. Yield of rainfed barley is much lower not only due to less moisture availability in soil but also on account of poor nutrients (Sawarkar and Goydani, 1996). Amount of $\mathrm{N}$ applied to barley had to manage to insure that $\mathrm{N}$ is available throughout the growing season due to its important role in enhancing both vegetative and reproductive development. Under dry land conditions, barley fertilization considered as vertical factor to maximize yield and to water use efficiency. Also, the productivity of barley is affected by biofertilization most prominent. Utilization of associated bacteria to help increase nitrogen amounts in the barley rhizosphere appears to be a possible route for sustainable barley production in low rainfed areas. The increase in barley grain yield following inoculation with Azospirillum spp. was attributed to one or more of the following factors 1- Bacterial nitrogen fixation, 2- Bacterial production of growth hormones and 3- Increase in plant nutrient uptake. Therefore, the aim of this study was to enhancing barley productivity in North Western Coast of Egypt under rainfed conditions by using optimum relationship (portion) between catchment and cultivated areas with mineral nitrogen and 
biofertilization. It is hoped that the obtained results with the present study would help to obtain barley grain production by using the avoimentioned factors under rainfed conditions of Egypt.

\section{MATERIALS AND METHODS}

Two field experiments were carried out in flood plain of Wadi Hashim, Raas El-Hekma Region, at East Mersa Matrouh, Matrouh Governorate, North Western Coast of Egypt, during two winter growing successive seasons (2011/2012 and 2012/2013) to study the effect of strip size of water harvesting (catchment): cultivated area and (mineral nitrogen and biofertilization (microbein)) on yield, yield attributes and water use efficiency of Giza 126 barley (Hordeum vulgare L.) cultivar under rainfed conditions. The ratios of catchment to cultivated area as water harvesting treatment, were 1:1, 2:1, 3:1 and $4: 1$ by leaving alternate strips bare for surface runoff to cropped area as well as flat soil cultivated (without leaving catchment area) as a control. The slope percentage was measured by contour map. For land preparation, cultivated area plowing to rectangular time the catchment area was prepared by cleaning surface soil, plowing, and compact the soil surface using special rolling. A level terrace, constructed a gently sloping (3\%) catchment area serves as the cultivated area which stores the harvesting water. Each strip was divided into two parts: The upper part, referred to as the catchment area and the lower, down slope part called cultivated area using as collector area when rain intensity exceeds the infiltration rate (IR) in the uncultivated, some of the water flows downhill into the cultivated grain where it is stored in the root zone. The cultivated area of the experimental unit was $6 \mathrm{~m} \times 6 \mathrm{~m}\left(36 \mathrm{~m}^{2}\right)$ and the catchment area was different according to the different treatment i.e. 36, 72, 108 and $144 \mathrm{~m}^{2}$ as shown in Table (1). Barley grains were sowed in 23 November 2011 and 29 November 2012 at a rate of $30 \mathrm{~kg} / \mathrm{fed}$. in the first and second season respectively. Grains were sowed with certain rate of the cultivated strip and the grains were covered. Small earth dikes were conducted between the strips to prevent rainoff water movements from the strip to another. The area of the experimental plot was $36 \mathrm{~m}^{2}(6 \mathrm{~m}$ length and $6 \mathrm{~m}$ width, every plot with 6 rows, with wetness $15 \mathrm{~cm}$ between row to another) Barley was harvested on 12 May 2012 and 24 April 2013 in the first and second season respectively. Soil samples were taken just before the sowing date for physical and chemical analysis as shown in Table (2). 
Table (1). Strip size of water harvesting (catchment): cultivated area $\left(\mathrm{m}^{2}\right)$ Relation between

Harvesting

Cultivated area
$\mathrm{H}: \mathrm{C}$
(catchment) area $\left(\mathrm{m}^{2}\right)$
$\left(m^{2}\right)$

\begin{tabular}{ccc}
\hline Control & Without catchment area & 36 \\
$1: 1$ & $36(6 \times 6)$ & 36 \\
$2: 1$ & $72(6 \times 12)$ & 36 \\
$3: 1$ & $108(6 \times 18)$ & 36 \\
$4: 1$ & $144(6 \times 24)$ & 36 \\
\hline
\end{tabular}

$\mathrm{H}=$ Harvesting (catchment) area $\left(\mathrm{m}^{2}\right)$ and $\mathrm{C}=$ Cultivated area $\left(\mathrm{m}^{2}\right)$

\section{Strip water harvesting (catchment): cultivated area}

Five treatments for the relationship between harvesting (catchment) and cultivated area as shown in Table (1). The cultivated area of the experimental unit was $6 \mathrm{~m} \times 6 \mathrm{~m}\left(36 \mathrm{~m}^{2}\right)$, the catchment area was differed according to the following treatments i.e. $36,72,108$ and $144 \mathrm{~m}^{2}$.

\section{Mineral nitrogen and biofertilization (microbein)}

-Without mineral nitrogen and uninoculation.

$-10 \mathrm{~kg} \mathrm{~N}$ as $\mathrm{NH}_{4} \mathrm{NO}_{3}(33.5 \% \mathrm{~N}) / \mathrm{fed}$.

$-20 \mathrm{~kg} \mathrm{~N}$ as $\mathrm{NH}_{4} \mathrm{NO}_{3}(33.5 \% \mathrm{~N}) / \mathrm{fed}$.

-Biofertilizer [Microbein (Psedomonnas sp. + Azotobacter sp. + Azosprillum sp.

+ Bacillus megaterium)].

$-10 \mathrm{~kg} \mathrm{~N}$ as $\mathrm{NH}_{4} \mathrm{NO}_{3}(33.5 \% \mathrm{~N}) / \mathrm{fed}$. with biofertilization (microbein). $-20 \mathrm{~kg} \mathrm{~N}$ as $\mathrm{NH}_{4} \mathrm{NO}_{3}(33.5 \% \mathrm{~N}) / \mathrm{fed}$. with biofertilization (microbein).

Source of bio-fertilizer (microbein): Agricultural Research Center, Giza, Egypt.

Grains were inoculated with microbein at the rate of $0.8 \mathrm{~kg} / \mathrm{fed}$. The welted barley grains were inoculated with microbein just before planting. Arabic gum $(5 \%)$ was used as an adhesive agent.

Table (2). Some physical and chemical properties of the experiment soil

\begin{tabular}{|c|c|c|c|c|c|c|c|c|c|c|c|}
\hline \multirow{3}{*}{$\begin{array}{l}\text { Soil } \\
\text { depth } \\
(\mathrm{cm})\end{array}$} & \multirow{3}{*}{$\begin{array}{c}\text { Particle } \\
\text { Sand } \\
(\%)\end{array}$} & \multirow{3}{*}{$\begin{array}{r}\text { ze dis } \\
\text { Silt } \\
(\%)\end{array}$} & \multirow{3}{*}{$\begin{array}{l}\text { ibutior } \\
\text { Clay } \\
(\%)\end{array}$} & \multirow{3}{*}{$\begin{array}{l}\text { Texture } \\
\text { class }\end{array}$} & \multirow[b]{3}{*}{$\mathrm{pH}$} & \multicolumn{2}{|c|}{ Chemical } & \multicolumn{3}{|c|}{ Analysis } & \\
\hline & & & & & & EC & $\mathrm{CaCo}_{3}$ & & ation & neq & \\
\hline & & & & & & $\mathrm{dS} / \mathrm{m}$ & & $\mathrm{Ca}$ & $\mathrm{Mg}$ & $\mathrm{K}$ & $\mathrm{Na}$ \\
\hline $0-15$ & 57 & 28 & 15 & sano & 8.5 & 0.85 & 15.9 & 1.6 & 1.4 & 1.3 & 4.5 \\
\hline $15-30$ & 61 & 27 & 12 & sandy loam & ర. & 1.6 & 23.2 & 3.4 & 2.1 & 1.1 & 10.0 \\
\hline
\end{tabular}

Table (3). The received precipitation $(\mathrm{mm})$ during the two growing seasons \begin{tabular}{ccccccccccc} 
growing season & Sep. & Oct. & Nov. & Dec. & Jan. & Fep. & Mar. Apr. & May. Total \\
\hline $2011 / 2012$ & 1.0 & 0.3 & 49.0 & 57.1 & 1.3 & 5.3 & 3.8 & 0 & 0 & 117.8
\end{tabular}

$\begin{array}{lllllllllll}2012 / 2013 & 0 & 2.9 & 15.9 & 16.4 & 54.8 & 0 & 0 & 0.2 & 0 & 90.2\end{array}$

Source: Weather Under Ground, Best Forecast from http://trmm.gsfc.nasa.gov. (2011/2012 and 2012/2013). 


\section{Meteorological Data}

Meteorological data were obtained from Weather Under Ground, Best Forecast from http://trmm.gsfc.nasa.gov., for the two growing seasons (temperature, relative humidity, dew point and wind speed) had shown in Table (4) for the first and second season respectively.

\section{Table (4). Meteorological data of Mersa Matrouh location through out $2011 / 2012$ and $2012 / 2013$ growing seasons}

\begin{tabular}{|c|c|c|c|c|c|c|c|c|}
\hline \multirow[b]{2}{*}{ Period } & \multicolumn{4}{|c|}{ First season $(2011 / 2012)$} & \multicolumn{4}{|c|}{ Second season $(2012 / 2013)$} \\
\hline & $\begin{array}{c}\text { Air } \\
\text { temperature } \\
\left({ }^{0} \mathrm{C}\right)\end{array}$ & $\begin{array}{c}\text { Dew } \\
\text { point }\left({ }^{0} \mathrm{C}\right)\end{array}$ & $\begin{array}{c}\text { Relative } \\
\text { humidity } \\
(\%)\end{array}$ & $\begin{array}{l}\text { Wind } \\
\text { speed } \\
(\mathrm{km} / \mathrm{h})\end{array}$ & $\begin{array}{c}\text { Air } \\
\text { temperature } \\
\left({ }^{0} \mathrm{C}\right)\end{array}$ & $\begin{array}{l}\text { Dew } \\
\text { point } \\
\left({ }^{0} \mathrm{C}\right)\end{array}$ & $\begin{array}{c}\text { Relative } \\
\text { humidity } \\
(\%)\end{array}$ & $\begin{array}{l}\text { Wind } \\
\text { speed } \\
(\mathrm{km} / \mathrm{h})\end{array}$ \\
\hline $1-10 / 11 / 2011$ & 18.6 & 11.8 & 63.8 & 11.5 & 22.6 & 17.9 & 74.4 & 15.5 \\
\hline $11-20 / 11 / 2011$ & 16.7 & 11.8 & 76.0 & 16.5 & 20.3 & 12.7 & 62.0 & 12.2 \\
\hline $21-30 / 11 / 2011$ & 15.0 & 10.8 & 75.4 & 11.4 & 18.4 & 13.4 & 75.2 & 13.5 \\
\hline $1-10 / 12 / 2011$ & 15.4 & 9.3 & 68.0 & 14.6 & 17.9 & 8.1 & 54.4 & 22.6 \\
\hline $11-20 / 12 / 2011$ & 15.1 & 9.5 & 70.3 & 11.0 & 15.5 & 7.9 & 62.1 & 25.4 \\
\hline $21-30 / 12 / 2011$ & 13.8 & 7.1 & 66.5 & 18.9 & 14.3 & 8.9 & 70.6 & 17.4 \\
\hline $1-10 / 1 / 2012$ & 13.5 & 6.4 & 67.1 & 23.9 & 12.6 & 8.1 & 73.5 & 37.0 \\
\hline $11-20 / 1 / 2012$ & 12.0 & 6.4 & 70.1 & 21.2 & 13.8 & 8.1 & 69.7 & 27.7 \\
\hline $21-30 / 1 / 2012$ & 13.0 & 7.2 & 68.5 & 24.7 & 14.5 & 6.6 & 61.3 & 19.7 \\
\hline $1-10 / 2 / 2012$ & 11.5 & 3.8 & 62.6 & 19.8 & 14.4 & 6.7 & 61.8 & 20.4 \\
\hline $11-20 / 2 / 2012$ & 12.8 & 5.7 & 63.4 & 17.9 & 13.8 & 6.1 & 60.9 & 18.4 \\
\hline $21-30 / 2 / 2012$ & 13.7 & 8.2 & 70.7 & 19.5 & 16.6 & 8.9 & 66.4 & 17.4 \\
\hline $1-10 / 3 / 2012$ & 13.3 & 9.5 & 76.3 & 32.5 & 15.7 & 9.1 & 66.6 & 19.2 \\
\hline $11-20 / 3 / 2012$ & 15.0 & 6.6 & 57.7 & 24.5 & 18.2 & 7.9 & 56.9 & 25.0 \\
\hline $21-30 / 3 / 2012$ & 15.6 & 10.7 & 73.3 & 14.5 & 18.4 & 9.4 & 60.0 & 22.2 \\
\hline 1-10/4/2012 & 19.1 & 11.7 & 65.5 & 18.5 & 20.6 & 9.8 & 55.3 & 23.0 \\
\hline $11-20 / 4 / 2012$ & 19.6 & 6.9 & 47.5 & 20.7 & 16.3 & 10.6 & 67.2 & 16.9 \\
\hline $21-30 / 4 / 2012$ & 18.7 & 12.8 & 69.7 & 13.9 & 18.2 & 13.6 & 72.9 & 12.8 \\
\hline $1-10 / 5 / 2012$ & 20.1 & 14.8 & 70.5 & 12.3 & 20.3 & 15.7 & 72.5 & 13.2 \\
\hline $11-20 / 5 / 2012$ & 21.4 & 14.9 & 66.6 & 16.8 & 21.9 & 14.7 & 64.3 & 19.3 \\
\hline $21-30 / 5 / 2012$ & 28.1 & 18.3 & 86.7 & 17.4 & 24.6 & 14.6 & 60.5 & 18.3 \\
\hline
\end{tabular}

At harvest, number of tillires $/ \mathrm{m}^{2}$, number of spikes $/ \mathrm{m}^{2}, 1000$ grain weight (g), biological yield ( $\mathrm{kg} / \mathrm{fed}$.), grain yield ( $\mathrm{kg} / \mathrm{fed}$.), straw yield ( $\mathrm{kg} / \mathrm{fed}$.$) , harvest$ index $(\%)$ and water use efficiency $\left(\mathrm{kg} / \mathrm{m}^{3}\right)$ were estimated.

Harvest index (\%) = Grain yield (kg/fed.) / Biological yield (kg/fed.) x 100 .

Biological, grain and straw yield were calculated from the whole weight of the experimental plot.

Water use efficiency $\left(\mathrm{kg} / \mathrm{m}^{3}\right)=$ Grain yield $\left(\mathrm{kg} / \mathrm{fed}\right.$.) $/ \mathrm{Et}_{\mathrm{a}}\left(\mathrm{m}^{3} / \mathrm{fed}\right.$.) according to (Giriappa, 1983).

$\mathrm{Et}_{\mathrm{a}}=$ precipitation $(\mathrm{mm}) \times 4.2$

\section{Statistical analyses}

Data were arranged and analyzed as a strip plots design according to (Cochran and Cox, 1963) with four replicates, whereas the vertical strips were occupied by strip harvesting water and the horizontal strips were devoted to mineral nitrogen and biofertilization treatments. New L.S.D. test at a level of $5 \%$ of significance was used for the comparison between means according to (Waller and Duncan, 1969). 


\section{RESULTS AND DISCUSSION \\ Effect of strip size of water harvesting system (catchment): cultivated area:}

Results in Table (5) showed that catchment area ratios had a significant effect on all the studded characters except number of tillires $/ \mathrm{m}^{2}$ in the first season. Maximum values were obtained by using catchment area ratio of $4: 1$ (four times of cultivated area), while minimum values were recorded by control (without leaving catchment area). Different characters witch mentioned in Table (5) had the similar trend concerning the effect of catchment area on yield and yield components (number of tillires $/ \mathrm{m}^{2}$, number of spikes $/ \mathrm{m}^{2}, 1000$ grain weight, biological yield, grain yield, straw yield and harvest index) and water use efficiency. These results were true in the two growing studied seasons i.e 2011/2012 and 2012/2013. Data in Table (5) indicated that the measurements values of yield, yield components and water use efficiency could be sequenced in descending order as follows: water use efficiency, grain yield, biological yield, straw yield, 1000 grain weigh, harvest index, number of spikes $/ \mathrm{m}^{2}$ and number of tillires $/ \mathrm{m}^{2}$ for first and second season respectively, as affected by decreasing of size of catchment area. The increasing percentage above control treatment (without leaving catchment area) up to four times of cultivated area were 57.4 $57.4,40.6,33.4,32.1,12.1,8.2$ and $2.3 \%$ respectively, in the firs season, while it were $59.259 .0,40.1,33.1,32.8,13.1,8.8$ and $3.1 \%$ respectively, in the second season. The different effect on the studied characters might be due to the effect of increasing the catchment area increased the precipitation area accompanying an increasing in water yield for cultivated area subsequently increasing the soil moisture content in barley root. zone. These results were in harmony with obtained by Abelardo (1996) who mentioned that weather harvesting can be increased the soil moisture content by holding more run-off water from catchments area for the cropped area which reflected on increasing plant growth due to increasing in think capacity. Micro catchment water harvesting can improve soil moisture storage and prolong the period of moisture availability (Li et al., 2000). Also, Attia (2005) studied the effect of strip size of water harvesting system on yield, yield components and water use efficiency of wheat in flood plain of Wadi Medour, El-Qasr Region, West Mersa Matrouh, Matrouh Governorate, North Western Coast of Egypt. He reported that the strip water harvesting system had a significant effect on yield and its components i.e. number of tillers per plant, number of spike per $\mathrm{m}^{2}, 1000$ grain weight, biological yield, grain yield, straw yield, harvest index and water use efficiency. The lowest values were obtained by control treatment, while the maximum values were obtained by using the largest catchment area (5:1) (five times of cultivated area). 
Table (5). Effect of catchment area ratios and (mineral nitrogen and biofertilization) on yield, yield attributes and water use efficiency of barley plant Giza 126 at (2011/2012 and 2012/2013) growing seasons at East Mersa Matrouh under rainfed conditions

\begin{tabular}{|c|c|c|c|c|c|c|c|c|c|c|c|c|c|c|c|c|}
\hline \multirow[t]{2}{*}{ Treatments } & \multicolumn{2}{|c|}{$\begin{array}{l}\text { No. of tillires } \\
/ \mathrm{m}^{2}\end{array}$} & \multicolumn{2}{|c|}{$\begin{array}{c}\text { No. of } \\
\text { spikes } / \mathrm{m}^{2}\end{array}$} & \multicolumn{2}{|c|}{$\begin{array}{l}1000 \text { grains } \\
\text { weight }(\mathrm{g})\end{array}$} & \multicolumn{2}{|c|}{$\begin{array}{l}\text { Biological yield } \\
\text { (kg/fed.) }\end{array}$} & \multicolumn{2}{|c|}{$\begin{array}{c}\text { Grain } \\
\text { yield (kg/fed.) }\end{array}$} & \multicolumn{2}{|c|}{$\begin{array}{c}\text { Straw } \\
\text { yield (kg/fed.) }\end{array}$} & \multicolumn{2}{|c|}{$\begin{array}{c}\text { Harvest } \\
\text { Index (\%) }\end{array}$} & \multicolumn{2}{|c|}{$\begin{array}{c}\text { Water use } \\
\text { Efficiency }\left(\mathrm{kg} / \mathrm{m}^{3}\right)\end{array}$} \\
\hline & $11 / 12$ & $12 / 13$ & $11 / 12$ & $12 / 13$ & $11 / 12$ & $12 / 13$ & $11 / 12$ & $12 / 13$ & $11 / 12$ & $12 / 13$ & $11 / 12$ & $12 / 13$ & $11 / 12$ & $12 / 13$ & $11 / 12$ & $12 / 13$ \\
\hline \multicolumn{17}{|l|}{$\begin{array}{l}\text { Strip size of water harvesting } \\
\text { system (A): }\end{array}$} \\
\hline $\begin{array}{l}\text { Without catchment area } \\
(1: 1) \\
(2: 1) \\
(3: 1) \\
(4: 1)\end{array}$ & $\begin{array}{l}163.5 \\
164.9 \\
165.9 \\
167.1 \\
167.4 \\
\end{array}$ & $\begin{array}{l}141.1 \\
142.2 \\
143.3 \\
144.3 \\
145.5\end{array}$ & $\begin{array}{l}130.6 \\
133.8 \\
136.5 \\
139.3 \\
141.3 \\
\end{array}$ & $\begin{array}{l}107.5 \\
110.1 \\
112.3 \\
114.6 \\
117.0 \\
\end{array}$ & $\begin{array}{l}30.8 \\
34.6 \\
37.3 \\
39.2 \\
40.7 \\
\end{array}$ & $\begin{array}{l}27.4 \\
30.8 \\
33.2 \\
34.9 \\
36.3 \\
\end{array}$ & $\begin{array}{l}1824 \\
2024 \\
2215 \\
2379 \\
2564 \\
\end{array}$ & $\begin{array}{l}1440 \\
1599 \\
1749 \\
1880 \\
2018 \\
\end{array}$ & $\begin{array}{l}544.1 \\
648.2 \\
720.2 \\
788.7 \\
856.3 \\
\end{array}$ & $\begin{array}{l}395.3 \\
470.8 \\
523.8 \\
575.7 \\
628.7 \\
\end{array}$ & $\begin{array}{l}1280 \\
1376 \\
1494 \\
1591 \\
1708 \\
\end{array}$ & $\begin{array}{l}1044 \\
1128 \\
1225 \\
1304 \\
1390 \\
\end{array}$ & $\begin{array}{l}29.7 \\
31.9 \\
32.4 \\
33.0 \\
33.3 \\
\end{array}$ & $\begin{array}{l}27.4 \\
29.4 \\
29.8 \\
30.5 \\
31.0\end{array}$ & $\begin{array}{l}110.0 \\
131.0 \\
145.6 \\
159.4 \\
173.1 \\
\end{array}$ & $\begin{array}{l}104.3 \\
124.3 \\
138.3 \\
152.0 \\
166.0 \\
\end{array}$ \\
\hline New L.S.D. (0.05) & N.S. & 2.9 & 2.9 & 2.4 & 1.1 & 1.0 & 21.9 & 23.4 & 5.5 & 11.9 & 17.8 & 14.9 & 0.20 & 0.39 & 1.1 & 3.1 \\
\hline \multicolumn{17}{|l|}{$\begin{array}{l}\text { Nitrogen and microbein } \\
\text { fertilizer }(\mathrm{B}):\end{array}$} \\
\hline $\begin{array}{l}\text { Without fertilization } \\
\text { (control) }\end{array}$ & 157.5 & 135.6 & 127.8 & 104.7 & 33.3 & 29.6 & 1968 & 1546 & 589.8 & 418.7 & 1378 & 1127 & 29.8 & 26.9 & 119.2 & 110.5 \\
\hline $\begin{array}{l}10 \mathrm{Kg} \mathrm{N} / \mathrm{fed} . \\
20 \mathrm{Kg} \mathrm{N} / \mathrm{fed} . \\
\text { Microbein } \\
10 \mathrm{Kg} \mathrm{N} / \mathrm{fed} .+ \text { Microbein } \\
20 \mathrm{Kg} \mathrm{N} / \mathrm{fed} .+ \text { Microbein }\end{array}$ & $\begin{array}{l}166.0 \\
171.3 \\
160.4 \\
167.0 \\
172.3 \\
\end{array}$ & $\begin{array}{l}143.1 \\
147.6 \\
140.1 \\
144.3 \\
149.0 \\
\end{array}$ & $\begin{array}{l}136.5 \\
141.6 \\
131.6 \\
137.6 \\
142.7\end{array}$ & $\begin{array}{l}111.8 \\
116.0 \\
109.6 \\
113.9 \\
117.7 \\
\end{array}$ & $\begin{array}{l}36.5 \\
38.6 \\
34.2 \\
37.3 \\
39.4 \\
\end{array}$ & $\begin{array}{l}32.5 \\
34.4 \\
30.5 \\
33.2 \\
35.1 \\
\end{array}$ & $\begin{array}{l}2172 \\
2372 \\
2039 \\
2224 \\
2433 \\
\end{array}$ & $\begin{array}{l}1718 \\
1857 \\
1626 \\
1761 \\
1914 \\
\end{array}$ & $\begin{array}{l}697.7 \\
802.9 \\
617.7 \\
727.5 \\
833.6 \\
\end{array}$ & $\begin{array}{l}511.8 \\
573.0 \\
467.4 \\
537.1 \\
605.2 \\
\end{array}$ & $\begin{array}{l}1474 \\
1569 \\
1421 \\
1497 \\
1599 \\
\end{array}$ & $\begin{array}{l}1206 \\
1284 \\
1159 \\
1224 \\
1309 \\
\end{array}$ & $\begin{array}{l}32.0 \\
33.7 \\
30.2 \\
32.6 \\
34.1 \\
\end{array}$ & $\begin{array}{l}29.7 \\
30.7 \\
28.6 \\
30.4 \\
31.5 \\
\end{array}$ & $\begin{array}{l}141.0 \\
162.3 \\
124.8 \\
147.0 \\
168.5 \\
\end{array}$ & $\begin{array}{l}135.1 \\
151.3 \\
123.4 \\
141.8 \\
159.8 \\
\end{array}$ \\
\hline New L.S.D. (0.05) & 3.0 & 2.3 & 2.4 & 2.0 & 0.6 & 0.5 & 16.4 & 13.5 & 4.1 & 6.7 & 14.4 & 11.8 & 0.20 & 0.32 & 0.83 & 1.8 \\
\hline teraction: & 6.6 & 5.0 & 5.3 & 4.4 & 1.3 & 1.2 & 36.6 & 30.2 & 9.2 & 15.1 & 32.2 & 26.4 & 0.46 & 0.71 & 1.9 & 4.0 \\
\hline
\end{tabular}




\section{Effect of mineral nitrogen and biofertilization:}

Data in Table (5) showed that the effect of mineral nitrogen and biofertilization were significant on yield and yield components (number of tillires $/ \mathrm{m}^{2}$, number of spikes $/ \mathrm{m}^{2}, 1000$ grain weight, biological yield, grain yield, straw yield and harvest index) and water use efficiency in both seasons. Highest value of number of tillires $\left(172.3\right.$ and $\left.149.0 / \mathrm{m}^{2}\right)$, number of spikes $\left(142.7\right.$ and $\left.117.7 / \mathrm{m}^{2}\right), 1000$ grain weight $(39.4$ and $35.1 \mathrm{~g})$, biological yield (2433 and $1914 \mathrm{~kg} / \mathrm{fed}$.), grain yield (833.6 and $605.2 \mathrm{~kg} / \mathrm{fed}$.), straw yield (1599 and $1309 \mathrm{~kg} / \mathrm{fed}$.), harvest index (34.1 and $31.5 \%$ ) and water use efficiency (168.5 and $159.8 \mathrm{~kg} / \mathrm{m}^{3}$ ) in the first and second season respectively, were obtained as barley plants were fertilized by the interaction treatment $(20 \mathrm{~kg}$ $\mathrm{N} / \mathrm{fed}$. with biofertilization). Application of $80 \mathrm{~kg} \mathrm{~N} / \mathrm{fed}$. gave highest barley straw yield and yield components (Barsoum, 1994). These results were in harmony with those pointed by Rahim et al. (2013), who reported that there was a significant effect on barley yield and related characters by using chemical fertilizer. The effect was significant on grain yield, harvest index and biological yield by using bio-fertilizer, the traits of consumer interest such as highest grain yield, harvest index and biological yield were obtained with the application of (Azotobacter + Pseudomonas) as compared with noninoculation treatment. The traits such as grain yield, harvest index and biological were affected by interaction effects of both chemical and biofertilizers, the highest grain yield was thus due to the use of chemical fertilizer with Azotobacter Pseudomonas. Since, we can accept grain yield of barley by using $75 \%$ chemical fertilizer and inoculation with (Azotobacter + Pseudomonas). In general, the result of this investigation showed that the use of $75 \%$ chemical fertilizer along with dual inoculation (Azotobacter + Pseudomonas) could produce satisfactory yield of barley. Nitrogen fertilizer at a rate of 80 $\mathrm{kg} / \mathrm{ha}$. with both (Azotobacter + Azospirillum) inoculations was found to be the most responsive, with significantly increased in the maximum number of tillers and grain yield of barley. Azospirillum inoculation, Azotobacter inoculation and uninoculated control significantly differed between each to other (Tarun, 2013).

Generally, the increasing in parley yield and its attributes by mineral nitrogen and microbein inoculation might be due to: Azospirrillum brasilens which improve growth of plants and produce high growth parameters, nutrients content, protein content (Sawarker and Goydani, 1996). The counts of Azospirrillum spp. increased with increasing the growth period to reach their maximum values during the grain formation stage decreased (Zaghlloul et al., 1996). The grains inoculation with Azospirrillum brasilens increased the growth, leaf area and its duration, photosynthesis, transpiration stomatal conductance and grain yield compared with uninoculation (Panwar et al., 1990). Biofertilization which is low cost was beneficent with balanced fertilization system, save fertilizers, give additional increase in barley yield and protect the age ecosystem from pollution (El-Akabwy et al., 2001 and Berhanu et al., 2013).

\section{The interaction between strip size of water harvesting system} (catchment): cultivated area and (mineral nitrogen and biofertilization):

Concerning the effect of the interaction between catchment area ratio and (mineral nitrogen and biofertilization) analyses of variance showed a significant effect on yield and yield components i.e. number of tillires $/ \mathrm{m}^{2}$, number of spikes $/ \mathrm{m}^{2}, 1000$ grain weight, biological yield, grain yield, straw yield, 
Table (6). The interaction between catchment area ratios and (mineral nitrogen and biofertilization) on yield, yield attributes and water use efficiency of barley plant Giza 126 at (2011/2012 and 2012/2013) growing seasons at East Mersa Matrouh under rainfed conditions

\begin{tabular}{|c|c|c|c|c|c|c|c|c|c|c|c|c|c|c|c|c|}
\hline \multirow[t]{2}{*}{ Treatments } & \multicolumn{2}{|c|}{$\begin{array}{l}\text { No. of tillires } \\
/ \mathrm{m}^{2}\end{array}$} & \multicolumn{2}{|c|}{$\begin{array}{c}\text { No. of } \\
\text { spikes } / \mathrm{m}^{2}\end{array}$} & \multicolumn{2}{|c|}{$\begin{array}{c}1000 \\
\text { grains weight }(\mathrm{g})\end{array}$} & \multicolumn{2}{|c|}{$\begin{array}{l}\text { Biological yield } \\
\text { (kg/fed.) }\end{array}$} & \multicolumn{2}{|c|}{$\begin{array}{c}\text { Grain } \\
\text { yield (kg/fed.) }\end{array}$} & \multicolumn{2}{|c|}{$\begin{array}{c}\text { Straw } \\
\text { yield (kg/fed.) }\end{array}$} & \multicolumn{2}{|c|}{$\begin{array}{c}\text { Harvest } \\
\text { Index }(\%)\end{array}$} & \multicolumn{2}{|c|}{$\begin{array}{c}\text { Water use } \\
\text { Efficiency }\left(\mathrm{kg} / \mathrm{m}^{3}\right)\end{array}$} \\
\hline & $11 / 12$ & $12 / 13$ & $11 / 12$ & $12 / 13$ & $11 / 12$ & $12 / 13$ & $11 / 12$ & $12 / 13$ & $11 / 12$ & $12 / 13$ & $11 / 12$ & $12 / 13$ & $11 / 12$ & $12 / 13$ & $11 / 12$ & $12 / 13$ \\
\hline \multicolumn{17}{|l|}{ (Without catchment area): } \\
\hline Control & 148.3 & 128.1 & 116.7 & 95.4 & 28.8 & 25.6 & 1563 & 1228 & 436.7 & 309.1 & 1126 & 919 & 28.0 & 25.2 & 88.3 & 81.6 \\
\hline $10 \mathrm{~kg} \mathrm{~N} / \mathrm{fed}$. & 162.0 & 139.9 & 129.5 & 105.9 & 30.8 & 27.4 & 1761 & 1398 & 522.4 & 386.8 & 1239 & 1012 & 29.7 & 27.7 & 105.6 & 102.1 \\
\hline $20 \mathrm{~kg} \mathrm{~N} / \mathrm{fed}$ & 170.3 & 148.4 & 140.7 & 115.1 & 31.3 & 27.9 & 1982 & 1556 & 609.6 & 434.4 & 1372 & 1121 & 30.8 & 27.9 & 123.2 & 114.7 \\
\hline Microbein & 155.7 & 136.3 & 124.5 & 103.6 & 29.5 & 26.3 & 1725 & 1364 & 489.2 & 361.6 & 1236 & 1002 & 28.4 & 26.5 & 98.9 & 95.5 \\
\hline $10 \mathrm{~kg} \mathrm{~N} / \mathrm{fed} .+$ Microbein & 165.2 & 142.6 & 132.2 & 109.3 & 31.2 & 27.8 & 1839 & 1456 & 557.3 & 408.9 & 1282 & 1047 & 30.3 & 28.1 & 112.6 & 107.9 \\
\hline $20 \mathrm{~kg} \mathrm{~N} / \mathrm{fed} .+$ Microbein & 172.4 & 148.3 & 140.3 & 115.6 & 33.1 & 29.5 & 2075 & 1636 & 649.3 & 470.9 & 1426 & 1165 & 31.3 & 28.8 & 131.2 & 124.3 \\
\hline \multicolumn{17}{|l|}{ (1:1): } \\
\hline Control & 157.2 & 134.9 & 125.9 & 103.0 & 31.4 & 28.0 & 1861 & 1459 & 544.5 & 379.6 & 1316 & 1079 & 29.3 & 26.0 & 110.0 & 100.2 \\
\hline $10 \mathrm{~kg} \mathrm{~N} / \mathrm{fed}$ & 164.7 & 141.4 & 133.7 & 109.3 & 34.3 & 30.5 & 1996 & 1579 & 631.3 & 459.9 & 1365 & 1119 & 31.6 & 29.1 & 127.6 & 121.4 \\
\hline $20 \mathrm{~kg} \mathrm{~N} / \mathrm{fed}$ & 170.4 & 146.2 & 138.9 & 113.6 & 36.4 & 32.4 & 2181 & 1710 & 729.0 & 519.5 & 1452 & 1191 & 33.4 & 30.4 & 147.3 & 137.1 \\
\hline Microbein & 158.4 & 137.7 & 128.1 & 106.6 & 33.6 & 29.9 & 1887 & 1513 & 566.8 & 433.6 & 1320 & 1079 & 30.0 & 28.7 & 114.6 & 114.5 \\
\hline $10 \mathrm{~kg} \mathrm{~N} / \mathrm{fed} .+$ Microbein & 164.2 & 143.9 & 133.5 & 110.4 & 35.3 & 31.4 & 1995 & 1577 & 659.7 & 482.3 & 1336 & 1095 & 33.1 & 30.6 & 133.3 & 127.3 \\
\hline $20 \mathrm{~kg} \mathrm{~N} / \mathrm{fed} .+$ Microbein & 172.7 & 149.2 & 142.8 & 117.6 & 36.8 & 32.8 & 2227 & 1754 & 757.9 & 549.6 & 1469 & 1204 & 34.0 & 31.3 & 153.2 & 145.1 \\
\hline \multicolumn{17}{|l|}{ (2:1): } \\
\hline Control & 158.0 & 135.9 & 128.3 & 105.0 & 33.8 & 30.1 & 1992 & 1565 & 598.6 & 422.5 & 1393 & 1143 & 30.1 & 27.0 & 121.0 & 111.5 \\
\hline $10 \mathrm{~kg} \mathrm{~N} / \mathrm{fed}$ & 165.1 & 142.0 & 135.7 & 111.0 & 37.6 & 33.5 & 2184 & 1726 & 710.4 & 517.1 & 1474 & 1209 & 32.5 & 30.0 & 143.6 & 136.5 \\
\hline 20 kg N/fed. & 171.9 & 147.8 & 142.1 & 116.2 & 39.9 & 35.6 & 2412 & 1886 & 819.2 & 580.2 & 1593 & 1306 & 34.0 & 30.8 & 165.6 & 153.2 \\
\hline Microbein & 164.1 & 143.0 & 135.0 & 112.2 & 33.8 & 30.1 & 2027 & 1623 & 615.9 & 467.7 & 1411 & 1155 & 30.4 & 28.8 & 124.5 & 123.5 \\
\hline $10 \mathrm{~kg} \mathrm{~N} / \mathrm{fed} .+$ Microbein & 166.4 & 143.1 & 137.1 & 113.3 & 38.2 & 34.0 & 2223 & 1764 & 733.7 & 542.1 & 1490 & 1222 & 33.0 & 30.7 & 148.3 & 143.1 \\
\hline $20 \mathrm{~kg} \mathrm{~N} / \mathrm{fed} .+$ Microbein & 169.9 & 147.7 & 140.8 & 116.0 & 40.5 & 36.1 & 2449 & 1929 & 843.7 & 613.1 & 1605 & 1316 & 34.5 & 31.8 & 170.5 & 161.8 \\
\hline
\end{tabular}


Table (6). Cont.

\begin{tabular}{|c|c|c|c|c|c|c|c|c|c|c|c|c|c|c|c|c|}
\hline \multirow{2}{*}{ Treatments } & \multicolumn{2}{|c|}{$\begin{array}{l}\text { No. of tillires } \\
/ \mathrm{m}^{2}\end{array}$} & \multicolumn{2}{|c|}{$\begin{array}{c}\text { No. of } \\
\text { spikes } / \mathrm{m}^{2}\end{array}$} & \multicolumn{2}{|c|}{$\begin{array}{c}1000 \\
\text { grains weight }(\mathrm{g})\end{array}$} & \multicolumn{2}{|c|}{$\begin{array}{c}\text { Biological yield } \\
(\mathrm{kg} / \mathrm{fed} .)\end{array}$} & \multicolumn{2}{|c|}{$\begin{array}{c}\text { Grain } \\
\text { yield (kg/fed.) }\end{array}$} & \multicolumn{2}{|c|}{$\begin{array}{c}\text { Straw } \\
\text { yield (kg/fed.) }\end{array}$} & \multicolumn{2}{|c|}{$\begin{array}{c}\text { Harvest } \\
\text { Index (\%) }\end{array}$} & \multicolumn{2}{|c|}{$\begin{array}{c}\text { Water use } \\
\text { Efficiency }\left(\mathrm{kg} / \mathrm{m}^{3}\right)\end{array}$} \\
\hline & $11 / 12$ & $12 / 13$ & $11 / 12$ & $12 / 13$ & $11 / 12$ & $12 / 13$ & $11 / 12$ & $12 / 13$ & $11 / 12$ & $12 / 13$ & $11 / 12$ & $12 / 13$ & $11 / 12$ & $12 / 13$ & $11 / 12$ & $12 / 13$ \\
\hline \multicolumn{17}{|l|}{ (3:1): } \\
\hline Control & 161.3 & 138.7 & 132.7 & 108.5 & 35.0 & 31.2 & 2125 & 1670 & 657.3 & 466.0 & 1468 & 1204 & 31.0 & 28.0 & 132.8 & 123.0 \\
\hline $10 \mathrm{~kg} \mathrm{~N} / \mathrm{fed}$ & 168.6 & 145.0 & 140.5 & 114.9 & 39.0 & 34.8 & 2360 & 1870 & 774.5 & 570.4 & 1585 & 1300 & 32.8 & 30.5 & 156.6 & 150.6 \\
\hline $20 \mathrm{~kg} \mathrm{~N} / \mathrm{fed}$ & 169.6 & 145.8 & 142.2 & 116.3 & 42.3 & 37.7 & 2559 & 2003 & 893.0 & 637.1 & 1666 & 1366 & 34.9 & 31.8 & 180.5 & 168.2 \\
\hline Microbein & 162.3 & 141.3 & 134.7 & 111.9 & 35.9 & 32.0 & 2178 & 1748 & 674.8 & 516.7 & 1503 & 1231 & 31.0 & 29.6 & 136.4 & 136.4 \\
\hline $10 \mathrm{~kg} \mathrm{~N} / \mathrm{fed}$ & 169.7 & 145.6 & 141.8 & 117.1 & 40.3 & 35.9 & 2436 & 1932 & 809.1 & 598.1 & 1627 & 1334 & 33.2 & 31.0 & 163.5 & 157.9 \\
\hline $20 \mathrm{~kg}$ & 171.2 & 149.2 & 144.0 & 118.6 & 42.8 & 38.1 & 2618 & 2055 & 923.6 & 666.2 & 1694 & 1389 & 35.3 & 32.4 & 186.7 & 175.8 \\
\hline \multicolumn{17}{|l|}{$(4: 1):$} \\
\hline Control & 162.5 & 140.2 & 135.3 & 111.5 & 37.3 & 33.3 & 2300 & 1808 & 711.9 & 516.1 & 1588 & 1292 & 31.0 & 28.6 & 143.9 & 136.2 \\
\hline $10 \mathrm{~kg} \mathrm{~N} / \mathrm{fed}$ & 169.7 & 147.1 & 143.1 & 117.9 & 40.9 & 36.4 & 2558 & 2015 & 849.9 & 624.9 & 1708 & 1390 & 33.2 & 31.0 & 171.8 & 164.9 \\
\hline $20 \mathrm{~kg} \mathrm{~N} /$ fed. & 170.4 & 147.0 & 143.9 & 118.5 & 43.0 & 38.3 & 2727 & 2129 & 963.4 & 693.7 & 1763 & 1436 & 35.3 & 32.6 & 194.7 & 183.1 \\
\hline Microbein & 161.7 & 142.0 & 135.9 & 113.8 & 38.1 & 33.9 & 2377 & 1886 & 741.6 & 557.5 & 1636 & 1328 & 31.2 & 29.6 & 149.9 & 147.2 \\
\hline $10 \mathrm{~kg} \mathrm{~N} / \mathrm{fed} .+$ Microbein & 169.7 & 146.4 & 143.5 & 119.4 & 41.3 & 36.8 & 2626 & 2078 & 877.6 & 653.9 & 1748 & 1424 & 33.4 & 31.5 & 177.4 & 172.6 \\
\hline $20 \mathrm{~kg} \mathrm{~N} / \mathrm{fed} .+$ Microbein & 172.9 & 150.4 & 145.8 & 120.9 & 43.8 & 39.0 & 2796 & 2194 & 993.5 & 726.4 & 1803 & 1468 & 35.5 & 33.1 & 200.8 & 191.7 \\
\hline New L.S.D. (0.05) & 6.6 & 5.0 & 5.3 & 4.4 & 1.3 & 1.2 & 36.6 & 30.2 & 9.2 & 15.1 & 32.2 & 26.4 & 0.46 & 0.71 & 1.9 & 4.0 \\
\hline
\end{tabular}


harvest index and water use efficiency for both seasons as shown in Table (6). Maximum values were obtained by the interaction treatment (catchment area ratio of $4: 1$ and $20 \mathrm{~kg} \mathrm{~N} / \mathrm{fed}$. with biofertilization). Maximum value of number of tillires $\left(172.9\right.$ and $\left.150.4 / \mathrm{m}^{2}\right)$, number of spikes $\left(145.8\right.$ and $\left.120.9 / \mathrm{m}^{2}\right), 1000$ grain weight (43.8 and $39.0 \mathrm{~g}$ ), biological yield (2796 and $2194 \mathrm{~kg} / \mathrm{fed}$.), grain yield (993.5 and $726.4 \mathrm{~kg} / \mathrm{fed}$.), straw yield (1803 and $1468 \mathrm{~kg} / \mathrm{fed}$.), harvest index (35.5 and $33.1 \%$ ) and water use efficiency $\left(200.8\right.$ and $191.7 \mathrm{~kg} / \mathrm{m}^{3}$ ) throughout the first and second season respectively. Above mentioned results might be due to the interaction between catchment area ratio and (mineral nitrogen and biofertilization) on barley yield important to produce constant and economically attractive yield and the water use efficiency increased remarkably with increasing nitrogen level due to the higher grain yield and the favorably affected plant height (Kumar et al., 1990). No. of spikes $/ \mathrm{m}^{2}$, grain weight/spike and grain yield weight were favorably affected by increasing water supply and nitrogen levels (Singh and Bhan, 1998). Using the strip size of strip water harvesting system (5: 1) (contributed area five times of cultivated area) + mineral nitrogen and biofertilizer (50 kg N/fed. with microbein) gave the highest grain yield and enhanced the most of plant characters, yield, its components and water use efficiency for winter wheat under rainfed conditions (Attia 2005). These results might be due to the application of nitrogen also, favored relatively more moisture extraction soil profile probably due to higher grain yield. The amount of fertilizer and the barley yield were parabolic when the amount of water supply was constant. The amount of nitrogen and water content at a positively alternative effect. Fertilizer application can improve barley efficiency and increase barley yield. In the rainfed conditions the amount of increase in barley yield by fertilizer can be arranged as follow: with rainfall yield larger than year with minimum rainfall larger than with low rainfall. (Ryan et al., 2009).

\section{Discussion between first season and second season}

Yield, yield components and water use efficiency in the first season expressed higher values than those obtained in the second season. This may be du to:

1. The high quantity and regular distribution of precipitations in winter season. Also, quantity and time of rainfall precipitations were early in the first season that affected early cultivation and plant adaptation reflected on improvement growth stage, adaptation of barley plants to meteorological factors which suitable to physiological process and increasing plant life period.

2. Up to $60 \%$ of precipitation was concentrated in January month (54.8 $\mathrm{mm}$ ) as shown in Table (3) of the second season whereas, it was useless for vegetation growth.

The difference between the two seasons for grain yield, yield components and water use efficiency might had been caused by different environmental conditions between two seasons, i.e. quantity and distribution of rainfall over seasons which was different through out the two seasons (Table 3 ).

The efficiency of runoff farming system was affected by the annual rainfall amount and rainfall distribution.

In rainfed agriculture, yield production was permanently dependent on the amount and distribution of rainfall. Seasonal rainfall is the most important factor affecting yields in the rainfed areas of West Asia and North Africa, up to 82 percent of the variation in grain yield was found to be determined by 
seasonal rainfall (Christiansen, 1982). The percentage of variation in grain yield explained by annual precipitation varied with variety and species $(5-13 \%$ in barley and $31-79 \%$ in wheat), the distribution of precipitating was the major factor effecting grain yield, although it varied with variety and explained $72-92 \%$ of the variation in barley and from $75-98 \%$ in wheat (Hadjichristodoulou, 1982).

\section{CONCLUSIONS}

Using the ratio between catchment area and cultivated area of (4: 1) (catchment area four times of cultivated area) + mineral nitrogen fertilizer at a rate of $20 \mathrm{~kg} \mathrm{~N} / \mathrm{fed}$. with inoculating grains by microbein as a source of biofertilization gave the highest grain yield, yield components and water use efficiency for winter barley under rainfed conditions.

\section{REFERENCES}

Abelardo, A.W. 1996. Sustainability and economic variability of cereals grown under alternative treatments of water-harvesting in Highland Balochistan, Pakistan. J. Sustainable, Agric., 8 (1) 159-164.

Attia, M.A. 2005. Sowing wheat (Triticum aestivum L.) at Matrouh. (Ph.D) Thesis, Fac. of Agriculture, Ain Shams Univ. Egypt.

Barsoum, M.S. 1994. Response of barley to IAA-presoaking grain treatment and nitrogen fertilization under Wadi-Sudr conditions at South Sinai. Annals of Agricultural Science, Moshtohor, 32(3):1355-1369.

Berhanu, G.W., T. Kismanyoky and K. Sardi. 2013. Effect of nitrogen fertilization and residue management on the productivity of winter barley (Hordeum vulgare L.). Acta Agronomica Hungarica, 61(2):101111.

Boars, M., M. Degrand, R.A. Feddes and J. Ben-Asher. 1986. A linear regression model combined with a soil water balance model to design micro-catchments for water harvesting in arid zone. Agric. Water Manage, 11:187-206.

Brown, L.R. 2000. Population growth sentencing millions to hydrological poverty. World Watch Institute Alert, $21^{\text {st }}$ June.

Christiansen, M.N. 1982. In breeding plants for less favorable environments. (eds. M.N. Christiansen and C.F. Lewis), 1-11, Willew Interscience, N.Y.

Cochran, W.G. and G.M. Cox. 1963. Experimental Designs, 2 nd. Edi. 306309. Asia Publishing House, Bombay. Calculate, New Delhi, Mod Sas Luck now, London, New York.

El-Akabwy, M.A., A.A. Abd El-Magid, I.A. Ibrahim and N.O. Monged. 2001. A trail to optimum $\mathrm{N}$ fertilizer by using balanced mineral fertilizer or biofertilizer to wheat grown in Nile Delta. Egypt. J. Apple. Sci., 16 (5): 79-98.

Giriappa, S. 1983. Water use efficiency in agriculture. Agricultural development and rural transformation unit for Social and Economic change Bengalese. Oxford \& IBH Pulal. Co. U.K.

Hadjichristodoulou, A. 1982. The effect of annual precipitation and its distribution on grain yield of dry land cereals. J. Agric. Sci., Camb, 27 (1): 261-270. 
Jiang, Y., L.X. Yan and M. YuJun. 2013. Water and energy conservation of rainwater harvesting system in the Loess Plateau of China. Journal of Integrative Agriculture, 12(8):1389-1395. 36 ref.

Kumer, A., D.K. Sharma and H.C. Sharma. 1990. Response of wheat (Triticum aestivum L.) to irrigation and nitrogen in sodic soils. Indian J. Agron., 40 (1): 38-42.

Li, F.R., S. Cook, G.T. Geballe and W.R. Bruch. 2000. Rainwater harvesting agriculture: an integrated system for water management on rainfed land in China's semiarid areas. Ambio, 29 (8): 477-483.

Panwar, J.D.S., M. Pandy and Y.P. Abrol. 1990. Effect of Azospirillum brasilenes on photosynthesis, transpiration and yield of wheat under low fertility conditions. Indian. J. Plant. Physiology, 33(3): 185-189.

Prinz, D. and S. Wolfer. 1999. Traditional techniques of water management to cover future irrigation water demand. Z. f. Bewasserungswirtschaft, 34 (1), 41-60. ISSN 0049-8602.

Rahim, N., A. Sadegh and A. Mirzaei. 2013. Effects of inoculation with Pseudomonas putdown on yield and some of the important agronomic traits in barley (Hordeum vulgar L). International Journal of Agronomy and Plant Production, 4 (7): 1602-1610.

Rees, D.J., M. Islam, F. Rehman, A. Samiullah and S.H. Raza. 1989. Rainfed crop production system of upland Balochistan. 2) Barley (Hordeum valgare). MART/AZR Research report No. 51. ICARDA, Quetta Pakistan.

Reiz, C., P. Mauldr and L. Begemann. 1986. Water harvesting for plant production. World Bank Tech Paper 91 Waashigtion.

Rockstrom, J., L. Karlberg, S.P. Wani, J. Barron, N. Hatibu, T. Oweis, A. Bruggeman and J. Qiang. 2010. Managing water in rainfed agriculture - the need for a paradigm shift. (Special Issue: Comprehensive Assessment of Water Management in Agriculture.). Agricultural Water Management, 97(4):543-550.

Ryan, J., M.A. Monem and A. Amri. 2009. Nitrogen fertilizer response of some barley varieties in semi-arid conditions in Morocco. Journal of Agricultural Science and Technology, 11(2):227-236. 26 ref.

Said, M.A. 1998. Response of barley to mineral and biofertilizer in the newly reclaimed lands. M. Sc. Theses. Fac. Agric. Alex. Univ.

Sawarkar, S.D. and B.M. Goydani. 1996. Effect of fertilizerand Azospirillum on grain yield of rainfed wheat. Indian J. Agron., 41 (3): 409-411.

Singh, S. and V.M. Bhan. 1998. Response of wheat and associated weeds to irrigation regime, nitrogen and 2, 4-D. Indian J. Agron., 43(4): 662-667.

Tarun, T., J.S.A. Kumar and J. Dawson. 2013. Effect of different levels of nitrogen and biofertilizers on growth and yield of barley (Hordeum vulgare L.). Advance Research Journal of Crop Improvement, 4(1):5961.5 ref.

Waller, R.A. and D.B. Duncan. 1969. A base rule for the symmetric multiple comparison problem. A mex. Stat. Assoc. J., 1485-1503.

Zaghloul, R.A., A.A. Amer and M.H. Mostafa. 1996. Effecincy of some organic manures and biofertilization with Azospirillum brasilenes for wheat maturing. Annals. Agric. Sci., Moshtohor, 34(2): 627-640. 


\title{
الملخص العريى \\ تقييم إنتاجية الشعير تحت الظروف المطرية بوادى هاشم (شرق مطروح)
}

\author{
محمود عبد العزيز جمعة'، إبراهيم فتح الله رحاب'، منير صبحى برسوم'، محمد قناوى محمد؟ \\ ا ـ قسم الإنتاج النباتى - كلية الزراعة (سابا باشا) - جامعة الإسكندرية \\ r. قسم الإنتاج النباتى - شعبة البيئة وزراعات المناطق الجافة - مركز بحوث الصحراء - مصر
}

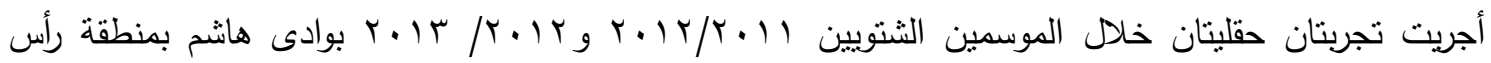

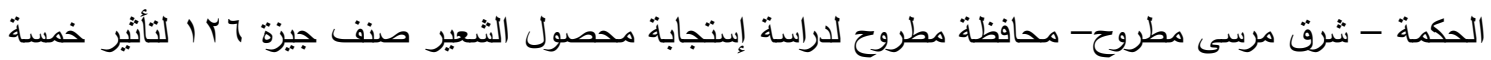
معاملات من نظام حصد مياه الأمطار عن طريق النسب بين المساحة المخصصة لحصد مياه الأمطار والمساحة

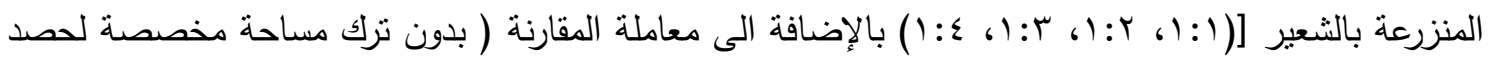

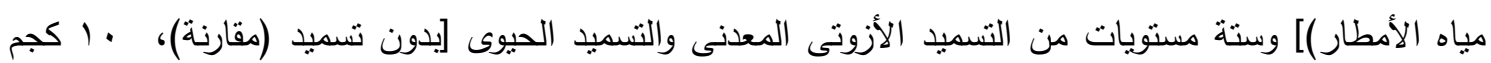

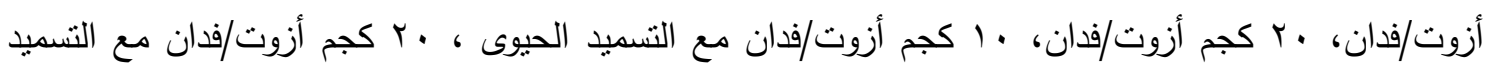
الحيوى] وكانت درجة ميول الأرض (إنحدار الأرض) ب\%ة. صمدت التجربة فى نظام الثرائح المتعامدة حيث إحتلت معاملات نسب شرائح المساحة المخصصة للجريان السطحي للمياه : المساحة المنزرعة الثرائح الرأسية ووزعت معاملات التسميد الأزوتى المعدنى و التسميد الحيوي فى الثرائح الأفقية فى أربع مكررات. أوضحت المباه النتائج زيادة محصول الثعبر ومكوناته (عدد السنابل فى المتر المربع، وزن الألف حبة (دليل الحبة)، المحصول

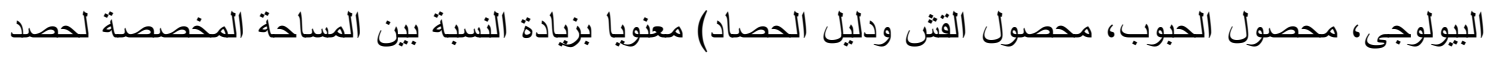
مياه الجريان السطحى: المساحة المنزرعة وذلك مقارنة بالمعاملة التى لم يترك فيها مساحة مخصصة لحصد مياه

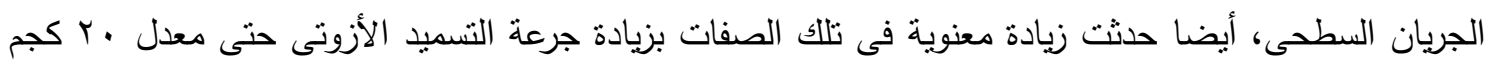
ن/فدان مع معاملة الحبوب بالتسميد الحيوى (ميكروبين)، تبين من الدراسة أيضا حدوث زيادة معنوية تدريجية فى في

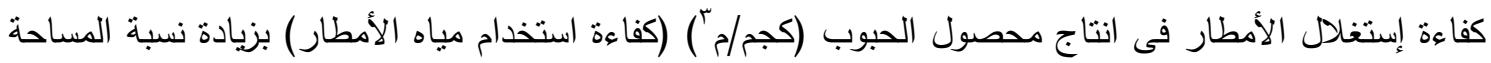
المخصصة لحصد مياه الجريان السطحى إلى المساحة المنزرعة وأيضا بزيادة معدل التسميد الأزوتى مع المعاملة بالتسميد الحيوى مقارنة بمعاملة الكنترول وذلك فى كلا الموسمين، بينما زاد عدد الأشطاء فى المتر المربع معنويا بزيادة النسبة بين المساحة المخصصة لحصد مياه الجريان السطحى : المساحة المنزرعة فى الموسم الثانى فقط وبزيادة جرعة التسميد الأزوتى مع معاملة الحبوب بالتسميد الحيوى فى الموسمين، وقد تحققت أقصى قيم للصفات

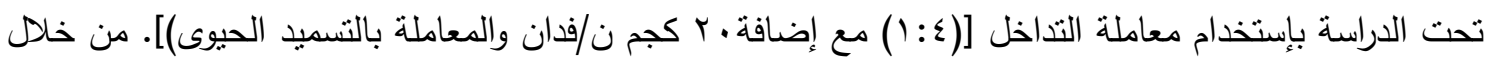
هذه الدراسة وجد أن إستخدام النسبة بين المساحة المخصصة لحصد مياه الجريان السطحى والمساحة المنزرعة (؛:1) (المساحة المخصصة لحصد مياه الجريان السطحى نساوى أربعة أضعاف المساحة المنزرعة) وتسميد

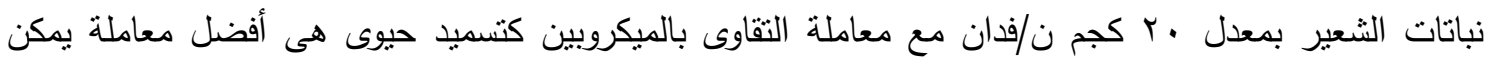
الإستعانة بها فى زراعة محصول الشعير فى وادى هاشم بمنطقة رأس الحكمة-شرق مرسى مطروح-محافظة مطروح 